\title{
Thaksinomics in Light of the Heterodox View on Economic Development
}

\author{
Istvan Rado*
}

The victory of the People Power Party in the 23 December 2007 general elections in Thailand ultimately illustrated former Prime Minister Thaksin Shinawatra's (2001 2006) unbowed popularity in most parts of the country. The election result was all the more impressive when one takes into account that the figurehead of the People Power Party, Thaksin himself, had been literally absent for sixteen months. The coup against Thaksin's Thai Rak Thai (TRT) government on 19 September 2006 had drawn on widespread dissatisfaction within the urban middle-class, sparked by Thaksin's authoritative and alleged corruptive practices. This dissatisfaction was especially visible in early 2006, when anti-Thaksin rallies took place in Bangkok. The coup makers, led by General Sonthi Boonyaratkalin, tried to legitimize the overthrow by stating several reasons, such as the rift in Thai society, corruption, power abuse, and lese majeste charges. During its term, the military-installed government under Prime Minister Surayud Chulanont more or less effectively banished everything associated with Thaksin. Popular policies were either removed or renamed and media coverage on the deposed Prime Minister restricted, among other things.

In early 2008, shortly after the elections, top executives of the People Power Party announced a revival of most policies introduced during the TRT government's period. Thaksin's socio-economic policies have constituted the main reason for his sustained popularity. "Thaksinomics" - the development strategy during his term - claimed to be an alternative to the "Washington Consensus," which through powerful institutions, such as IMF and World Bank, promote neoliberal policy making (through export orientation, attraction of foreign direct investment, minimal market intervention by the state, liberalization, privatization, the rule of law etc.).

Aside from Thaksinomics, another set of development theories has emerged to challenge orthodox - meaning neoliberal - economic theory. The latter type shares with Thaksinomics the perception that orthodox economic theory as promoted by the IMF usually fails to solve the economic problems of crisis-ridden developing countries. Moreover, some nations have achieved economic success despite ignoring such liberal policies, China being the prime example here. This "heterodox" view on economic development first emerged within the neoliberal school, but it has slowly become an alternative to it (Sabel, 2005, p. 4). Whereas the global institutions IMF and World Bank still promote economic development according to the neoliberal model, the heterodox view on economic development seems to increasingly have gained ground within institutions of the United Nations. ${ }^{1}$ As the development model of this school of thought includes all factions within societies, it ensures democracy and compliance with human rights.

Since the Thaksinomist development strategy is likely to shape Thailand's future under the banner of the People Power Party, this paper will outline the most promi-

\footnotetext{
* Istvan Rado is a PhD candidate in the Department of Political Science at the University of Vienna (Austria) and a visiting scholar in the Department of Political Science at Thammasat University (Thailand).
} 
nent features of the approach. In doing so, a more conclusive description will be presented than what is already available in studies covering only single aspects of the recent developments. Strengths and shortcomings of both single policies, and the development strategy as a whole will be highlighted as well. Aside from interpreting macroeconomic data, Thaksinomics will be contrasted with the heterodox development model in order to add other than purely economic standards as part of a brief evaluation of the Thai strategy.

\section{The Heterodox View on Economic Development}

Authors such as Dani Rodrik and Charles Sabel have criticized the Washington Consensus for its "institutional endowment" approach, also known as the "big-bang approach" (Sabel, 2005, p. 4; UN-DESA, 2005, p. 125). Whereas the former term suggests that economic growth is contingent on a predetermined bundle of factors, the latter implies that introducing market-friendly instruments will inevitably result in higher growth and economic development. Most authors promoting the heterodox view refer to the case of China as to make their point that a gradual and piecemeal introduction of reforms is a key to sustainable development. The theorists explain China's success with the compatibility of its reforms with the country's unique institutional setting. Moreover, it is suggested that development is a learning process in which the state and private actors combine their efforts in identifying appropriate policy actions, either targeted to specific economic sectors or the economy as a whole (provision of laws, infrastructure, laboratories etc.).

Rodrik in particular points out the processual emphasis of this developmental approach and states that "the analysis of industrial policy needs to focus not on the policy outcomes - which are inherently unknowable ex ante-but on getting the policy process right" (Rodrik, 2004, p. 3). In this model, where neither outcomes nor concrete policies are defined, the government collaborates with private companies by together overcoming informational and coordination constraints in building up industries. The rationale of this idea is that public and private actors pool their respective resources, which are - due to different perspectives - complementary in the process of problem identification and policy implementation. The relationship between both actors is, however, distinct from earlier developmental theories, which suggest that an authoritarian state dictates policies in a top-down approach; the new ideal in order to optimize the effectiveness of public-private collaboration is that of "embeddedness", where the "ties that connect citizens and public officials [span] across the publicprivate divide" (Evans, 1996, p. 180). Evans, as well as Rodrik, recognizes the threat of corruption imminent to close relationships between bureaucrats and business people. They therefore promote either powerful internal norms or a balance between full embeddedness and complete autonomy. Instead of fostering rent seeking, these relationships should facilitate the building-up of trust and social capital.

This public-private partnership towards developmental ends leads us to another characteristic feature of heterodox economic theory: the formation of networks, or clusters. Michael Porter has prominently outlined the relevance of cluster formation in his book "The Competitive Advantage of Nations" (1990). Although Porter described national clusters as predominantly private-private partnerships (encompassing firms of related industries, research institutions etc.), his treatment of the case for developing countries is not entirely clear; in parts he seems to sympathize with authoritarian, developmental regimes at an early stage of development (see Porter, 1990, p. 552). 
According to him, the government may target policies to the advantage and upgrading of selected industries. Later authors building on this theory, such as Rodrik, have not only included embedded governmental agencies in the model, but also civil society. Another difference between Porter and authors such as Rodrik and Sabel, consists in the latter abandoning the idea that successful industries can be identified ex ante. A broad consensus on the economic and political benefits of network building in the age of globalization has also fostered literature on both the functioning and design of networks (see for example Sabel, 2005, pp. 37-50; Messner, 1995, pp. 317-24 and pp. 326-34).

Figure 1: Sectors of Thai Society

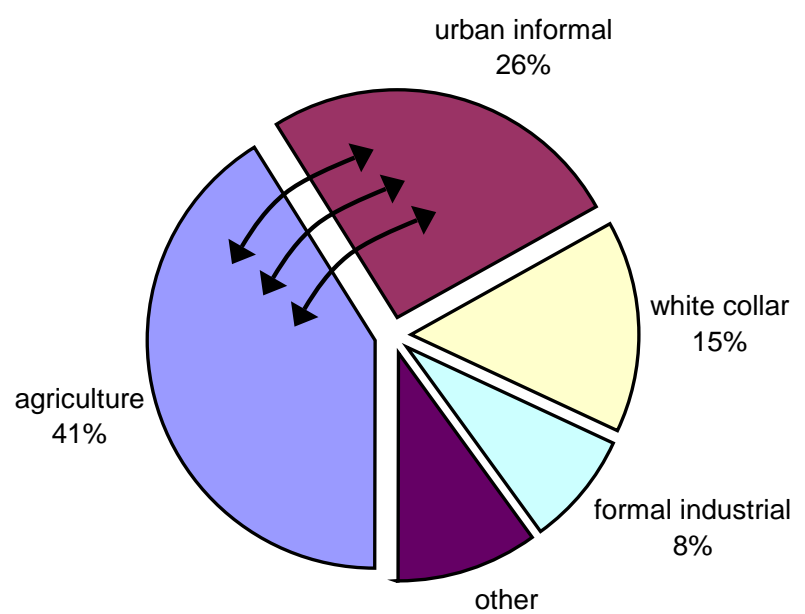

The formal working class - meaning those with relatively permanent jobs in enterprises of some scale - is very small, around 8 percent of the working population. The middle class, meaning anyone with a white-collar job including bureaucrats, professionals, and managers is around 15 percent The majority of the society, about two-thirds of the workforce, are in agriculture or the urban informal sector- vendors, mom and- pop stores, services, small enterprises, illegal businesses and a big casual workforce floating between many jobs. People move back and forth between agriculture and the urban informal sector.

Source: Pasuk in Bangkok Post, 31 July 2007.

The central state itself stands above vested interests and should not pursue goals other than the "common good." Hence, it is primarily ascribed a referee role inside networks; its main activity is seen as to ensure a favorable environment for a functioning market, for social cohesion and for a scaling-up of innovative networks. Some of the above authors agree that in every developing country there are functioning institutions and bases for the building-up of social capital, although such often-insulated institutions are typically not revealed in official aggregate figures (Sabel, 2005, pp. 29/30). Instead of trying to identify promising industries, based on the notion of a "comparative advantage" vis-à-vis other economies, the central government should identify such institutions. As the building blocks for capacity building through networks, these institutions trigger a process of removing constraints on development. The state must then ensure the ability of such networks or clusters to constantly upgrade and combine 
with other societal sectors (scaling-up).

Collaboration inside such networks requires a culture of dialogue that is immune to the domination by vested interests; the policy outcome must serve society as a whole. As mentioned, Evans promotes powerful rules in order to avoid rent seeking by governmental agencies. Others, such as Messner, moreover advocate informal rules that originate from trust and a shared culture. "Moral rules of the game" come into play here, deriving from what Messner calls "cultural deep structures" (Messner, 1995 , p. 184). The need for ethics and moral norms today is a topic that is in discussion for the global economic setting as well (Earth Dialogues, 2002, p. 4). It is interesting that although these concerns are increasingly being raised due to the social inequalities intensified by the forces of globalization, most theorists refer to such diffuse terms as "cultural deep structures", ethics, and "collective identity". If it is value systems that are an important answer to both today's problems (unsustainable and unjust economic order) and solutions (networks), then such terms are too vague to be of any help. Instead, religions should be recognized as grown value systems which have developed and which include ethical and moral norms proven over thousands of years. Perhaps this fact will be given more attention in future discussions on the functioning of the current economic system and intra-network collaborations. Signs of such a perception already exist, as on the occasion of the "Earth Dialogues Forum" in Lyon, France in February 2002. Here religions were ascribed a potential leadership role "in the sustainable development debate" (Earth Dialogues, 2002, p. 7).

\section{Thaksinomics}

Thaksin's economic policies can be understood against the background of Thailand's economic situation following the 1997 financial crisis. In 2001, when Thaksin took office as Prime Minister, the economy grew at 2.2 percent, compared to an average growth rate of ca. 8.6 percent between 1990 and 1996 (the pre-crisis period; see Bank of Thailand, 2007). The Thai economy is highly export-oriented (in 2001 exports accounted for about 57 percent of GDP) and since the crisis, most export-oriented industry is under transnational control.

The country faced a high unemployment rate and a sharp incline in poverty levels, due to the economic contraction in 1998, when the economy shrunk by 10.8 percent. Non-permanent, or "informal" workers were especially heavily hit by the crisis. This in turn directly affected the incomes of rural households, as these depended to a great extent on remittances from informal urban employment, e.g. in the construction business (Pasuk, 31 July 2007). The capacity of the government to tackle these social problems was limited due to high public household debt (peaking at 57.6 percent of GDP in 2001) and the conditions imposed by the IMF restructuring programs following the crisis (including cuts in government spending, closure of bankrupt financial institutions and private companies or market liberalization).

In the pursuit to get Thailand back on track to become a fully industrialized country, the TRT-government undertook a number of schemes targeted at the domestic economy and, later, at foreign investors. Motivated against the background of the social structure of the Thai population (see diagram below), and the resulting recognition that wide parts of Thai society (mainly in rural areas) are excluded from the benefits of economic development, Thaksin introduced expansionary fiscal policies to foster entrepreneurship and purchasing power among the rural poor.

These policies mainly include the "one-million village fund", a "people's bank", a

22 | Journal of Contemporary Eastern Asia, Volume 7, No.1 
three-year debt moratorium for farmers, a 30-Baht health-care scheme, and the "OneTambon-One-Product (OTOP)" scheme. As in the post-crisis period private banks were still struggling with non-performing loans, Thaksin used "state-owned commercial banks together with specialized banks" "quasi-fiscal" manner (Conroy, 2004, p. 8). These banks were under the supervision of the Ministry of Finance, but the cost of the lending programs was kept off budget initially. To take the case of the village fund, 70,000 communities received a million Baht to be forwarded as credit to individuals to assist micro-business activities. The limit for individual borrowers was set at 20,000 Baht. In practice, the average amount granted to borrowers was about half the amount. As there are often no reliable assessments on both the implementation and the outcome of Thaksin's povertyalleviation policies, the success of the village fund credit scheme is hard to evaluate. Official reports stating that the default rate is between 2 and 3 percent seem hardly reliable (see Conroy, 2004, p. 9). Though the poverty rate decreased during the implementation period, the extent to which the scheme contributed to this development cannot be assessed either. Regarding the use of the credit grants, a study of Thailand's National Institute of Development Administration suggests that only 21 percent of the micro-credits directed to farmers were used for productive investments (The Economist, 5 February 2005, p. 24). The rest was spent either for consumption or to pay back higher-interest loans.

Another attempt at boosting rural entrepreneurship was the establishment of the "One Tambon One Product (OTOP)" scheme: here, several state financial institutions were required to provide loans for local village businesses. An American academic describes the scheme as follows (Looney, 2003, p. 6):

This program is nationwide, covering nearly all of Thailand's 7,252 districts. One Tambon is predicated on the idea that every Thai tambon (subdistrict) has a variety of specialized local products. The key assumption of the project is that each community has a comparative advantage in one or more of these traditional products. The project's role is to assist the communities in modernizing the production and distribution process of these products so that they can be competitive at the national and international levels. The government's role is to identify candidate products and then to assist their development through providing necessary support for their eventual success.

The program is clearly intended to find new niches in foreign markets and develop new winners that will provide an alternative to the foreign direct investment-based and mass produced exports products that the country has been fast losing to China and other countries in the region with cheaper labor.

The scheme thus aimed at the building-up of core competencies and consequently, of competitiveness domestically and internationally. Robert Looney indicates some early results quoting government figures ${ }^{3}$, according to which

[...] total sales of village enterprises under the program [are put] at $\$ 558$ million in 2002, with an average profit margin of 26 percent. Their products are also finding their way to the shelves of luxury shops in Japan, the United States and Europe, thus enabling the village producers to earn four 
or five times more on each item than when sold in the local market (Looney, 2003, p. 6).

A negative outcome seemed to be, however, that most of the villages turned out to produce similar goods and were therefore unable to meet demand accordingly. The shortcomings of the above credit-driven programs (including the debt moratorium for farmers) also posed threats to the banks involved in the government programs. Under the government schemes, which promoted easy money to everyone, usual standards of creditworthiness were ignored. Although these financial institutions held government guarantees on their debt instruments, such relaxed standards could moreover deteriorate the credit behavior of borrowers over the long term. While in retrospective the credit programs have incurred losses and thus proved to be unsustainable in their current form, the post-Thaksin performance of two major banks pursuing the lending programs, the BAAC and GSB, shows that both banks are still profitable and continue implementation (Kate, 2007).

An interesting approach to enhance the creditworthiness of poor lenders was the governments "capital creation" program, introduced towards the end of 2003. Based on the idea of the Peruvian economist Hernando de Soto, the government sought to legally recognize undocumented assets held by the poor, such as land assets, public pavement assets or intellectual property assets (Looney, 2003, p. 6/7). Assets that were formerly held on customary or illegal grounds were thereby turned into capital. The Thaksin government pursued the program mainly by distributing land titles. Although the implementation of the capital creation scheme was not immune to threats, either - in the form of further indebtedness ${ }^{4}$ - the idea not only provided the poor with collateral enabling them to acquire credit from commercial banks, but also resulted in a wider inclusion of the underground economy into the formal economy.

The 30-Baht health-care scheme, on the other hand, was a typical welfare policy. The initial plan was to merge existing risk protection schemes and include those 18.5 million Thais whom those programs did not cover. These programs, introduced over a forty-year period prior to to the universal health care scheme, include the following (BMJ, 2004, p. 103):

Civil servants' medical benefit scheme-introduced in the 1960s for civil servants and their dependants

Low income card scheme-introduced in the 1970s, providing free care to low income families and individuals, elderly people, children under 12 years, and people with disabilities

Voluntary health card scheme-predominantly rural; introduced in the 1980s and funded through equal matching of household and Ministry of Public Health payments

Social security scheme-introduced in the 1990s; it protects workers only and is mandatory.

The integration of the above schemes into the 30-Baht program failed after resistance from government departments, civil servants and trade unionists. The government thus postponed the plan by establishing the "National Health Security Office" to oversee both the 30-Baht scheme and the risk protection schemes. Eventually, "the civil service and social security schemes [would] be merged into a single universal coverage scheme by decree should that become politically acceptable in the future" (BMJ, 2004, p. 103). The 30-Baht program was financed by budgets of the Ministry of Pub- 
lic Health and additional funding by the government. Each province employing and financing contractor units for primary care undertook the implementation of the scheme. These units (about five to seven in each province) are in charge of providing primary health care to all citizens that register with it. Each of them oversees a network of one hospital and all health centers in the district.

Although the scheme must be appreciated for giving the poor access to public health care provisions for the first time, there are several shortcomings that arose from the initial stage of implementation. One such shortcoming was the lack of adequate financing: the capital provided by the Ministry of Public Health did not wholly cover the lapse of individual user fees. Therefore many provinces and hospitals ran deficits. This shortage moreover affected resources available for medical teaching and research. As the 30-Baht scheme has shifted the emphasis away from hospitals to primary health centers, another problem arose from a shortage of medical staff, especially doctors, in these centers. Lastly, the BMJ-report cites a survey, according to which "those in the lowest income fifth were spending 7.5 percent of their income on health compared with an average of 1.6 percent and 0.1 percent for those in the social security and civil service schemes" and concludes that "This suggests that the scheme has not yet provided effective financial protection" (BMJ, 2004, p. 105).

Although the 30-Baht universal health care scheme is the most prominent, the TRT-government introduced more welfare-type policies, in the form of a life insurance scheme for the poor, scholarships and bicycle loans for poor students. Some of the policies overlap with measures stimulating demand, such as lowering the prices of typical household goods, e.g. computers and televisions. More obvious in the targeting of individual consumers was the fact that the government also eased credit card regulations, for instance. Moreover, Thaksin made it clear that his welfare-schemes were temporary measures to bridge the gap between the rich and the poor. Creating a welfare state was not his intention, as he himself emphasized (Pasuk, 2004, p. 5).

The above domestically-oriented schemes certainly have a potential to narrow the gap between the rural poor and the urban middle-class population. Through the lending programs, rural households have been given the opportunity to take part in the economic process both as consumers and producers. The national economy in turn can benefit through the inclusion of the informal economy and dormant human resources, which add to economic growth. However, this was only part of Thaksin's motives to pursue these domestically oriented activities. To him, an externallyoriented economy, such as the Thai economy, with exports encompassing 60 percent of GDP, meant being overly-prone to external shocks, as the 1997 financial crisis and the bird flu bitterly demonstrated. Thus, strengthening capitalism within Thailand by e.g. increasing domestic consumption to 60 percent of GDP (compared to 55 percent during his premiership) and reducing the share of exports in GDP to 50 percent (Looney, 2003, p. 4) would mean adjusting to the economic structure of most developed countries. At the same time, by targeting domestic industries with competitive potential, reliance on FDI would be reduced as well, thus allowing for the building-up of core-competencies within Thailand. Consequently, this would allow Thai businesses to move up the value-chain. For the purpose of helping to identify such highpotential industries, the "competitive-advantage"-guru himself, Michael Porter, was hired by the Thai government in 2002 . The competitive strengths presented by Porter included tourism, fashion, computer graphics and automobiles. National weaknesses were identified as well, namely low skills, weak technology and an obstructive government. Very much in line with his theory, he prescribed national cluster formation and a strong role for the government in targeting selected industries. Probably bearing 
in mind the need for technology transfers, the recommendations also included a bigger role for multinational corporations and FDI (Pasuk/Baker, 2004, pp. 113/14).

Although Thaksin's domestic market stimulus policies constitute the most innovative components of Thaksinomics, his measures included more common and outwardlooking policies as well. The structure of the Thai economy did not allow for a complete neglect of the outside world:

Since 1995, foreign trade had grown from 85 to 125 percent of GDP. Since 1990 FDI has increased more than 10 times. Tourist arrivals, FDI inflows, and foreign participation in the stock market had increased sharply. The GDP growth rate depended more than ever on exports, tourism, and international financial flows, and hence these areas could not be ignored. Increased export performance and tourism in $2002 / 3$ raised the GDP growth rates (Pasuk, 2004, p. 5).

In addition, Keynesian market interventions have a limited effect, the more open an economy is. According to NESDB figures, the government's domestic market policies contributed only slightly more than 13 percent of total GDP.

\section{Table 1: Infrastructure projects}

\begin{tabular}{rlrr}
\hline \multicolumn{1}{c}{ Projects } & Period & \multicolumn{1}{c}{$\begin{array}{c}\text { Budget } \\
\text { (million Baht) }\end{array}$} \\
\hline 1 & The new city project at Nakhon Nayok & $2004-2012$ & 100,000 \\
2 & Khlong Prapa elevated roadway & $2005-$ & 20,000 \\
3 & Laem Pak Bia Bridge across the Gulf of Thailand & $2005-2008$ & 56,000 \\
4 & Bangkok Transport master plan (skytrains, subways) & $2004-2009$ & 397,800 \\
5 & High speed railway expansion projects & $2004-2009$ & 400,000 \\
6 & Expressways, outer-ring roads and connecting roads & $2004-2009$ & 44,728 \\
7 & New canal and river routes (11 projects) & $2004-2005$ & 7,899 \\
8 & Chao Phraya River bridges (4 projects) & $2004-2005$ & 11,060 \\
9 & Motorways (10 projects) & $2006-2010$ & 118,553 \\
& & & $\mathbf{1 5 6 , 0 4 0}$ \\
\hline
\end{tabular}

Source: Pasuk, 2004

The TRT-government took these facts into account and communicated to the public and the outside world that its domestic market policies were thought as a counterbalance to losses incurred through the external sector - exports, FDI and tourism. When these factors pick up, the domestic market policies would be relaxed. This strategy, called "dual track strategy", has become synonymous with Thaksinomics (see Looney, 2003, p. 4). Recognizing the negative relationship between openness and Keynesian instruments, Thaksin promoted this strategy to other ASEAN-members in order to create cross-country synergies. The administration also continued courting foreign investment: the government's rhetoric on economic issues aimed at increasing investor confidence, and FDI was sought mainly in the sectors of automobile parts, food, fashion, tourism and logistics design. The range of export markets was sought to be expanded to such countries as India, China, the Middle East and Africa (Pasuk, 2004, p. 6).

Big government projects were also launched under Thaksin's premiership in order to attract domestic and foreign investment, such as infrastructure projects (such as a "Bangkok Transport Master Plan" encompassing the skytrain and subway systems), regional centers of economic activity (one of the plans intended to attract more trade 
and investment to Chiang Mai, another plan was to create a science park in Phuket) etc. A centuries-old plan to cut a canal through Thailand to shorten the route between Europe and East Asia was considered as well; the cost for this project was estimated to be 35 billion USD (for the cost structure of the infrastructure projects see table 1 below).

Under Thaksin, the Thai economy opened up further through multiple bilateral free trade agreements with e.g. Australia, China and, still in negotiation, with Japan and the United States (the latter currently on hold). However, as the case of the telecommunications industry involving the agreement with Australia shows, the benefits of these treaties are not evenly distributed over all industries (Oskar Andesner, 2 September 2005, Bangkok; personal interview). The TRT-government only selectively pursued trade liberalization, as e.g. the "United States' Annual Trade Estimate Report on Foreign Trade Barriers" of 2004 demonstrates (Bangkok Post, 5 April 2004). According to the report, there still existed a number of business barriers in the form of high import tariffs and restrictions on foreign investors in several service sectors. In the telecommunication sector state-owned enterprises dominated the market. The last feature of Thaksin's economic policies to be mentioned here, although it is not an official part of Thaksinomics is the defense of big business interests of the survivors of the Asian Financial Crisis. As Pasuk and Baker point out regarding the structure of the Thai Rak Thai party (Pasuk/Baker, 2002, p. 9):

At the core of Thaksin's government [...] is a group of the biggest Bangkok business groups which have survived the crisis: Thaksin himself, the richest single entrepreneur; CP, the biggest conglomerate; Maleenont, the largest stock-holders on the stock exchange; Summit, one of the biggest Thaiowned manufacturing groups; and so on. Thailand's biggest business now controls the government.

Thus, most members of Thaksin's Thai Rak Thai party were prominent corporate leaders, who, according to Pasuk and Baker, had been shaken up by the 1997 crisis. In their view, the state had failed in protecting their interests, whereas Thaksin, a businessman like them, offered the opportunity to regain closer control over politics. The CP Group, Thaksin's former biggest competitor in the telecom industry, for instance, was the biggest backer of Thaksin's political rise at the end of the $1990 \mathrm{~s}^{5}$. Pasuk thus viewed Thaksin "as the leader of a big business project to seize the state in order to protect big business against both external and internal threats, and in order to achieve a 'great leap forward' into advanced capitalism." In contrast to all former Thai governments, the economist explained, "Thaksin and his allies want to manage the economy more actively" (Pasuk at a seminar in April 2004, Bangkok).

In the author's attempt to examine the outcome of Thaksin's domestic market stimuli, it has become evident that due to the lack of transparency (the credit lending programs were kept off-budget) the losses incurred by the schemes can only be estimated. There were no agencies involved in implementing the economic policies outlined above that were not closely associated with the government (see Surin, 2007, p. 4). Thaksin's premiership resembled the attitude of a Chinese patriarch heading a family business. His view on the nation was indeed that of a company in competition with other nations and he openly referred to himself as Thailand's CEO (Pasuk/Baker, 2004, p. 102). It is therefore not surprising that whenever Thaksin commented on his government's achievements, truth was sacrificed for the sake of good marketing (see for example Conroy, 2004, p. 5; as well as the footnote on p. 18). Traditionally, there 
is no space for criticism on decisions from the top in Chinese family businesses and thus, Thaksin had no appreciation for scrutiny by the media and the intelligentsia. Dissent by the opposition, NGOs and intellectuals was branded a danger to "national interests," the media was bribed through advertising money, and self-censorship in the print media became characteristic under the Thaksin regime.

Thaksin eagerly expanded his influence in all sectors of Thai society: By merging with smaller parties he built a solid power base of 377 out of 500 seats in the Lower House of Parliament following the 2005 elections (Surin, 2007, p. 6). The TRT party's political influence reached such accountability institutions as the Senate as well; Surin Maisrikrod quotes a Senator, for instance, stating that "the number of Senators who vote in favor of government keeps increasing between 50 and 80 (out of 200), especially when the government is determined to pass a bill which is favorable to the telecommunications businesses". Moreover, Thaksin appointed his relatives and close friends to powerful positions in the army and the police: a former classmate was appointed Commander-in-Chief, the husband of his wife's secretary became commander of the air force, and his brother-in-law acquired a key position in the Navy. How far Thaksin was able to go in his authoritarian grip on power was revealed by his brutal handling of the unrest in three Muslim-dominated provinces in the far South of Thailand (see Shuman, 2005, p. 18), as well as the extra-judicial killings of some 2,500 suspects during the war on drugs.

It was the army where Thaksin's attempts of control provoked tensions between the pro-Thaksin and anti-Thaksin groups, the latter headed by General Sonthi Boonyaratkalin. It was this power-struggle which eventually led to Thaksin's overthrow: in July 2006 General Sonthi removed Thaksin's allies in high ranks of the military from Bangkok to the provinces. The general was certainly well-aware of the probability that Thaksin would use the annual reshuffle of the armed forces on 30 September 2006 to remove him in turn (Murphy, 2006, p. 4; Surin, 2007, p. 13); the coup just eleven days prior to the event prevented this.

The problem seems to be that Thaksin's megalomania made him interfere directly with the king's own network (McCargo, 2005, p. 501). The origins of the monarchy's prominence stem from the military dictatorship era under Sarit Thanarat (1958-63). Sarit promoted the Thai monarchy in order to gain legitimacy for his holding power. Since that time, the relationship between the palace and the military has remained strong: the king's "right-hand-man" (Murphy, 2006, p. 3) since the early 1980s is former commander-in-chief General Prem Tinsulanonda, who acts as a link in the king's network reaching into governments over the span of twenty consecutive years, as well as the military and the major bureaucratic institutions. By setting up his own network as noted above, Thaksin sidelined what is called the "old elite" (Pasuk, 31 July 2007), including the military, judiciary and other sectors of the Thai bureaucracy that often stood under the patronage of the palace.

Thaksin was not only at odds with the king in terms of human resources, but also in terms of policy instruments: in the course of a military crackdown on the Islamic insurgency in Thailand's deep south, 85 demonstrators were killed, most of whom died handcuffed in the back of military trucks on 25 October 2004. The Prime Minister only reluctantly agreed to adopt more "soft measures" as advocated by the king and set up a National Reconciliation Commission (headed by Anand Panyarachun, who had been appointed prime minister twice by the king). However, Thaksin "sidelined the body and largely ignored its recommendations" (Murphy, 2006, p. 2). Certainly to the resentment of the king, Thaksin had won the support of the rural populations in a few years through his populist policies, whereas "The king took four dec- 
ades of hard work to become so adored and popular" (Thitinan Pongsudhirak, cited in Murphy, 2006, p. 2). By sidelining traditional bureaucratic channels in drawing direct support from the rural poor, Thaksin built his support on the same foundation as the king. However, he did so by promoting consumerism and a "you can get rich, too" attitude; an approach, which stood in stark contrast to the Buddhist-inspired "Sufficiency Economy Theory" championed by the king. Consequently, many people perceived him as disloyal to the monarch (Surin, 2007, pp. 11/12).

\section{The People Power Party and the 23 December 2007 general elections}

Through his alleged disrespect for the king's policy recommendations and for the sectors of society close to the palace, Thaksin contributed to the September 2006 coup, which resulted in his forced withdrawal from politics and the dissolution of his TRT party. Together with him, another 110 former party executives were banned from taking political positions for five years. Whereas Thaksin remained in self-imposed exile until recently, some of the remaining former party members formed parties of their own afterwards, namely the Ruam Jai Thai Chart Pattana party, Matchimathipattai, and the Puea Paendin party, all contesting the following general elections in late December 2007. The biggest fraction of politically-active ex-TRT members, however, joined the then little-known People Power Party (PPP) in July 2007. Since then, close allies of Thaksin have been among the key executives of the PPP. The sudden prominence of the party has been subject to extensive media coverage ever since, as it was perceived to be the resurrected TRT-party (The Nation, 3 August 2007). The fact that ten million voters rejected the charter of the new constitution drafted by the militaryinstalled interim government through a referendum in August 2007 further indicated that Thaksin still enjoyed a formidable power base mainly in the northern and northeastern parts of Thailand. After the PPP declared that they would run in the general election scheduled for 23 December, the party was expected to attract a large share of rural votes. A victory seemed likely to many observers (The Nation, 25 August 2007).

\section{Figure 2: Party emblem of TRT and PPP}
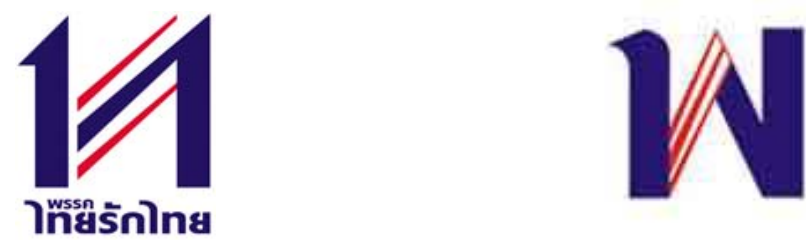

Left: The emblem of the now disbanded TRT party of Thaksin Shinawatra Right: The emblem of the PPP

With the nomination of former Bangkok governor Samak Sundaravej as party leader in late August, the party moreover gained a prominent right-wing spokesperson and defender of Thaksin during the tenure of the interim government. Samak's alleged involvement in the killings of pro-democracy protesters in October 1976 and in 1992 had earned him the reputation of a heavy-handed authoritarian figure and royalist. Although his current interpretation of the October 1976 incident during a CNN interview sparked fierce reactions from the Thai media ${ }^{6}$ (The Nation, 13 February 2008), this image helped prevent the PPP from the accusation of being disloyal to the monarchy. This in turn benefits Thaksin as well, since acts of lese majeste were among the four 
charges that had led to the coup in 2006. From the day Samak took office as head of the PPP, in public statements he made clear his conviction that the charges claimed by the coup-makers against the ousted prime minister were unfair.

\section{Figure 3: Initial election results 2007 (seats)}

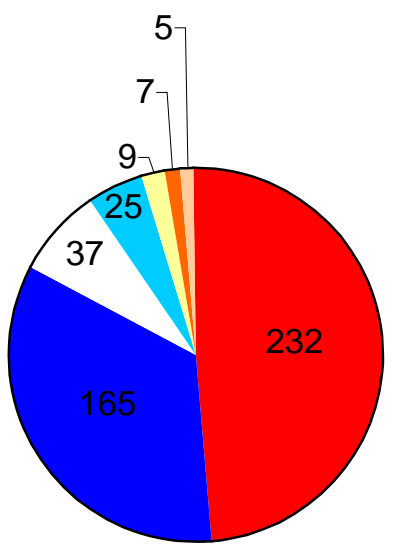

\begin{tabular}{|l|}
\hline$\square$ PPP \\
$\square$ Democrats \\
$\square$ Chart Thai \\
$\square$ Phuea Phaendin \\
$\square$ Ruam Jai Th. Ch. P. \\
$\square$ Matchimathipattai \\
$\square$ Phracharaj
\end{tabular}

Source: Nelson, 2008

In the run-up to the elections, the PPP also revealed its affinity to the disbanded TRT party to the still-high number of Thaksin-supporters by using a logo, which highly reminded one of the TRT emblem (see Figure 2). During the pre-election period, the support of many within the urban informal sector for the PPP became visible in Bangkok, as a high number of taxis and Tuk-Tuks featured the party logo on their vehicles. $^{7}$

The general election, which had become a competition between the pro-coup Democrats Party (with its leader Abhisit Vejjajiva) and the pro-Thaksin camp (PPP), brought a victory for the latter (see diagram below). Five hours after the election was concluded, Samak announced his intention to become Prime Minister at a press conference at the party headquarters (The Nation, 24 December 2007). During the next month the PPP succeeded in forming a coalition government with the Chart Thai party, Puea Paendin, Ruam Jai Thai Chart Pattana, Matchimathipattai, and Pracharaj, leaving the Democrats as the sole opposition party in parliament.

Table 2: Key cabinet ministers and Thaksin loyalists

\begin{tabular}{lll}
\hline & Background & Cabinet post \\
\hline Surapong Suebwonglee & Deputy Minister of Public & Deputy Prime Minister and \\
& Health, 2001-2005 & Minister of Finance \\
Somchai Wongsawat & Thaksin's brother-in-law & $\begin{array}{l}\text { Deputy Prime Minister and } \\
\text { Minister of Education }\end{array}$ \\
& Thaksin's legal advisor & Minister for Foreign Affairs \\
\hline
\end{tabular}

Source: "The secretariat of the Cabinet" - Assemblies LIV, LV, and LVII, 2008; Bangkok Post, 9 February 2008.

The new cabinet, in power since 6 February 2008, now includes some of Thaksin's close allies (see table 2). Prime Minister Samak has also taken the post as Defense Minister. It is speculated that the nomination of these persons in key positions serves attempts both to intervene into charges of corruption and power abuse made against

30 | Journal of Contemporary Eastern Asia, Volume 7, No.1 
Thaksin. A number of ministerial advisers have also been identified as "loyalists" of the former prime minister. The 23 February edition of the Bangkok Post quotes a source, according to which "the appointments were proof Mr Samak had no power in the coalition government", and "that the deposed prime minister had pulled the strings" (Bangkok Post, 23 February 2008).

\section{The Revival of Thaksinomics}

Even before the PPP-led government took office, Thaksinomist policies had not been entirely abolished. The interim government under Prime Minister Surayud Chulanont had promoted the king's Sufficiency Economy concept, which is regarded as an antidote to Thaksin's growth-oriented approach. As an article in "The Economist" - entitled: "Rebranding Thaksinomics" - points out, overlaps between both concepts do exist: the article mentions Thaksin's 30-Baht health care scheme and notes that "Judged by the sufficiency theory's own tenets, the five-year government of Thaksin [...] was wondrous" (The Economist, 11 January 2007). Bearing in mind the ex-premier's hyper-capitalist developmental approach, this is something of an overstatement, but certain schemes (and basic ideas) introduced by the TRT-government are indeed compatible with the Thai monarch's concept. ${ }^{8}$ The "Thailand Human Development Report 2007. Sufficiency Economy and Human Development" mentions three "rightly popular" schemes stemming from the Thaksin regime (UNDP, 2007, p. 61): The universal health care initiative, the rural debt relief program and the village-level development funds. The authors, however, raise the concerns already mentioned, particularly the use of the million Baht fund for other than investment purposes, the contribution of the scheme to rising private household debts and the lack of independent evaluation. The implementation of the health-care scheme is criticized for having been rushed and not thoroughly thought through. The result, according to the report, is that Thailand was developing a two-class health-care system. The OTOP scheme and the universal health-care program had therefore not been abolished, but modified and/or renamed. The latter scheme, for instance, has been changed into free medical treatment and renamed "Universal Healthcare Project"; the military government would have also liked to rename the OTOP-scheme, but the plan faced resistance from village communities, as the brand is already well established.

Since the PPP-led coalition government took over in early February 2008, the brand "Thaksinomics" is again becoming acceptable in the public domain. ${ }^{9}$ In late January 2008 the secretary general of the PPP already announced that the new government would revive up to ninety percent of TRT projects "scrapped after Mr Thaksin's forced departure" (Bangkok Post, 31 January 2008). These policies include the village fund scheme, a two- and three-digit lottery introduced by the TRT, and the CEO Governor scheme. Prior to the official policy announcement of the new coalition government on 18 February the reintroduction of a debt moratorium, a people's bank and investments in infrastructure and mega-projects were revealed as well (The Nation, 18 February 2008). In concrete terms the latter projects include an irrigation plan (by diverting water from the Mekong River to the north-eastern provinces), mass transit schemes for Bangkok, and train projects. The official policy announcement at the House of Representatives - while indicating the continuation of pre-coup economic policies - sounded less specific (policy statement of the cabinet, 18 February 2008). Certain paragraphs in the sections on the agricultural and industrial sectors seem to refer to the strengthening of the OTOP scheme, although the government itself chose a term, such as "agricultural procedure according to the theory of sufficiency econ- 
omy". The statement moreover includes commitments to strengthening certain industries, such as agriculture, tourism, services, and information technology. Fostering entrepreneurship and export promotion in new markets, namely China, India, Middle East, Africa, and Eastern Europe again remind one of TRT strategies.

Aside from economic issues, it is feared that the new government will treat public opposition and scrutiny in a similar manner as Thaksin had. Early signs of authoritarianism already exist. After Samak had denied the October 1976 massacre at Thammasat University during a CNN interview, the host of the Thai "Viewpoints" radio program presented evidence to counter Samak's interpretation. The program has since been closed, and Chirmsak Pinthong, the host, accused Minister Jakrapob Penkair of the Prime Minister Office of having intervened to force the closure (Bangkok Post, 15 February 2008). Government plans to re-launch a war on drugs cause concern among human rights activists and NGOs as well. The fact that Samak again - as it was the case when he had talked about the October 1976 incident - diminished the death toll during the Thaksin administration's war on drugs, does not restore confidence. The coalition government does not seem to hesitate to restore Thaksinocracy in all its facets alongside TRT economic policies: reshuffles in order to replace military-installed personnel by Thaksin's allies are already taking place. The head of the Department of Special Investigation (DSI), Sunai Manomai-udom, is apparently the first victim to be replaced by Pol Col Tawee Sodsong, "considered to be a close aide of former justice Minister and deputy leader of the dissolved Thai Rak Thai (TRT) party" (Bangkok Post, 23 February 2008). The DSI is currently investigating corruption charges against Thaksin and his wife, Khunying Potjaman. A meeting between Prime Minister Samak and army chief General Anupong Paojinda prior to the reshuffle of the armed forces in mid-March has taken place as well. Allegedly, the Prime Minister sought to influence the military reshuffle, which would help to avoid another coup.

\section{Conclusion}

Shortly after the military coup on 19 September 2006, the media inside and outside Thailand dispersed images of widespread support for the coup-makers within Bangkok's middle class. Yet it took only a few months for this support to crumble, as the new leaders seemed to lack a clear economic agenda (The Nation, 2 February 2007). Among the biggest part of Thailand's society - the rural population - the coup was rejected from the start. This, however, was less visible, as this large segment in Thai society has been widely ignored in the public sphere, which is dominated by the urban middle class. If the needs of the rural sector are highlighted in the media, it is done so by displaying the king's efforts through his agricultural development projects. Through these projects the king has been in touch with the rural people for over fifty years. The fact that the king's development projects ${ }^{10}$ are put into practice in coordination with the communities involved reveals his sensitivity for the importance of the rural people's political support. This sensitivity may have developed in part after the experience of the 1970s and early 1980s, when the Thai Communist Party had tried to build on the dissatisfaction of rural communities with the political-economic system of the time. After this threat to the constitutional monarchy had been overcome, rural communities have come entirely under the king's domain as a result of his development efforts. By viewing rural hardships as an object within the monarch's responsibility - or put differently, by viewing agriculturists as the children of a fatherly king (Dr. Supawud Saichua, 31 August 2007, at a lecture given at Thammasat University, 
Bangkok) - this large part of society was until recently ascribed a politically passive role.

With the political rise of Thaksin, the king's unique role for the rural people was challenged. In contrast to former governments, Thaksin realized the potential of the rural sector as a base for electoral support. His message was oriented towards the poor and Thaksin implemented everything he had promised prior to his premiership. Moreover, he emphasized that he was not part of the traditional Thai bureaucratic elite and instead was eager to exhibit himself as someone who ascended from humble roots. By referring to his own example, he gave the rural people the feeling that they could better their situation, too. Thus curiously, a businessman has become the populist leader and organ of the rural poor (Pasuk, 31 July 2007). His solution for this segment's problems however, differs fundamentally from the king's recommendation, which stresses the priority of self-sufficiency before engaging in the capitalist market. Shortly after the crisis, the royal concept seemed to appeal to many among the rural poor (Pasuk, 2005, pp. 162 and 165). Yet the alternative presented by Thaksin, which emphasized the prospect of wealth, turned out to be more alluring.

Thaksinomics has been termed a new paradigm for Asia in part due to the demise of the Washington Consensus (Looney, 2003, p. 2). In fact, ample state involvement did produce astonishing results in terms of economic growth (see Table 3). As the table shows, real GDP growth more than doubled a year after Thaksin took office as prime minister. Although this was helped by external factors - recovery of the global economy, low interest rates, rising prices for agricultural products - Thaksin's dualtrack policies directly contributed to the development.

Table 3: Real GDP Growth 2001 - 2005

\begin{tabular}{lccccc}
\hline Year & $\mathbf{2 0 0 1}$ & $\mathbf{2 0 0 2}$ & $\mathbf{2 0 0 3}$ & $\mathbf{2 0 0 4}$ & $\mathbf{2 0 0 5}$ \\
\hline$\%$ & 2.2 & 5.3 & 7.0 & 6.2 & 4.5 \\
\hline
\end{tabular}

Source: Bank of Thailand, 2007

In addition to the government's domestic market stimuli, export promotion (the second track) accounted for this economic expansion as well. The slow-down as indicated by the growth rate in 2005 was due to rising oil prices from late 2003 onwards. Since the Thai economy depends heavily on oil (Kate, 2003), the economic downturn was accompanied by a slowdown of private consumption and a rise of householddebts. Partly as a result of the government's credit lending programs, the debt level of the poorest households rose by 22 percent between 2002 and 2004. This reveals a major weakness of the credit lending schemes: in times of economic growth and low interest rates, defaults on loans are usually low, but things change when default rates rise due to a recession. As these risks were borne by the government's budget, the result was an increase in both public and private household debts. Nevertheless, as international credit rating agencies confirmed, Thailand's fiscal position has remained stable.

Whereas aggregate macroeconomic numbers are in favor of the Thaksin era, it has been shown above that most government induced programs had various shortcomings and showed mixed results. Given the manner in which these schemes were implemented - in a rushed top-down approach seeking fast results - this fact is hardly surprising. Such far-reaching projects need to be accorded with the institutions and groups that are being targeted; this is common sense for experts on development projects. Such processes may involve time-consuming procedures of decision-making, 
implementation and adjustments, but the outcome is more likely to be sustainable in the long run. Here lies the main difference between Thaksin's policy implementation and the requirements by promoters of the heterodox school of development: the latter do recognize a role for the state, but only as a mediator in the policy-making process, which involves all parts of society. State agencies may be embedded in such processes, but they do not have the capacity to centrally identify policy areas and prescribe policies from above.

The government schemes do not contradict the heterodox school (here the policy process is stressed, rather than its outcomes). However, the involvement of NGOs and experts with long-standing experience in development work may have brought different foci of policy-making. It has been mentioned above that the government only began granting legal land titles in the course of its capital creation scheme, after the rural poor had been targeted with credit lending programs. Yet how sustainable is any agricultural investment without legal use of land? How much inclined are farmers to invest in agricultural productivity beyond the subsistence level, if they must fear being chased off their land any time? Until today missing legal guarantees for land ownership are major causes of poverty in Thailand. Effective land reforms have never been implemented, nor are they a subject of debate in the public sphere. As pointed out by the "World Economic and Social Survey 2006" published by the UN-DESA (UNDESA, 2006, p. 134):

For countries with the majority of their population engaged in subsistence farming, increasing productivity in the agricultural sector is the key to initiating sustained long-term growth. Higher agricultural productivity [...] creates demands for manufactured goods and services and contributes to the development of non-agricultural sectors through their linkages with the agricultural sector.

In many contexts, low agricultural productivity constitutes a major binding constraint on sustained growth. Land reform is an effective means of easing this constraint by transferring ownership to farmers who operate the land $[\ldots]$

A big-bang approach - for which the Washington Consensus has been criticized - was inherent to Thaksin's implementation of his development strategy as well. Instead of a gradual introduction of reform, his government introduced various schemes simultaneously without tolerating dissent or public discussion. Yet, Thaksinomics must be credited for being the result of the specific circumstances of both the post-crisis period, as well as the Thai socio-economic structures in general. Thaksin appeared to have a stronger grasp of the latter than anyone else among the political elite.

It remains to be seen whether the PPP, which openly presents itself as the successor of the TRT party, has learned its lessons from the shortcomings of the latter. By having appointed Samak as the party-leader, and by having formulated a rather conciliatory policy statement, the PPP is apparently more careful with regard to the palace and the military. This however, could turn out to be a temporary strategy: Thaksin returned to Thailand towards the end of February 2008. By bringing his allies into powerful positions inside the Thai bureaucracy, the new government appears to be attempting to clear Thaksin from the charges made against him. It is very unlikely that Thaksin will be able to take the party's helm any time soon, although Samak, who is said to be merely a puppet of the former prime minister, lacks a comparable power base within his own party. As far as the Thai media is concerned, it has been shown 
above that the government has experienced a bad start to their power in office. Samak later tried to make up for his image through a token gesture, namely cooking a noodle dish for news reporters (Bangkok Post, 9 February 2008). Yet the media is still suspicious as to whether Samak is able to change his attitude towards public scrutiny. This in turn would be part of a more inclusive policy-making process, which is at the heart of the heterodox view on economic development.

\section{Notes}

1 See for example the "Industrial Development Report 2002/2003" by UNIDO; "World Economic and Social Survey 2006: Diverging Growth and Development" by UN-DESA, as well as the "Thailand Human Development Report 2007" by the UNDP. The Harvard economist Dani Rodrik had prepared his paper "Industrial Policy for the Twenty-First Century" (2004) for the UNIDO as well.

${ }^{2}$ In concrete terms, the following nine financial institutions are mentioned: Bank of Thailand, SME Development Bank, Industrial Finance Corporation of Thailand, Export-Import Bank, Bank for Agriculture and Agricultural Cooperatives, Small Industry Credit Guarantee Corporation, Government Savings Bank, Government Housing Bank, Krung Thai Bank (see Phongpaichit, 2004, p. 11).

3 As mentioned in the case of the million Baht scheme, official evaluations by the TRT-government should be viewed with some suspicion. In fact - as will be noted below - it has become clear after the September 2006 coup that all credit lending schemes have incurred losses.

${ }^{4}$ For a more detailed examination of risks inherent to the program see Conroy, 2004, p. 11

5 Two Chinese immigrant brothers founded the CP GROUP in 1921. Today, the son of a founder, Dhanin Chearavanont, is the conglomerat's CEO. His nephew-in-law, Watana Muangsook, used to be Industry Minister in the TRT government.

${ }^{6}$ In the course of the interview broadcast on February 9th 2008, Samak claimed that only "one unlucky guy" had died during the military deployment, even though a much higher number of deaths is documented by photographs and videos (Bangkok Post, 23 February 2008). With his comment, Samak also risked a rift within the PPP as well, considering the fact that some former TRT members had been present during the crackdown as student activists themselves.

The author was undertaking some research in Bangkok at the time and sometimes took a taxi home at night from his base at Thammasat University. During one of these rides, the driver started pointing at a campaign poster featuring Samak and other PPP executives. He then referred to them as the "good" guys, and termed the Surayud government the "mafia".

At an early stage of Thaksin's political career, he was surrounded by former student activists during the 1973 uprising against military dictatorship. Many of them had later joined the Communist insurgency in the countryside. Some policy schemes, such as the 30-Baht universal health-care scheme, were inspired by this group (Surin, 2007, p. 9). Curiously, many underlying ideas of the Sufficiency Economy have been articulated since the 1970 s by Thai academics from similar backgrounds.

9 During a presentation on "sufficiency economy" at the Thammasat University's "10th International Conference on Thai Studies" on 9 January 2008, the Australian academic Andrew Walker stated that during his research in Chiang Mai province he had come across certain projects initiated by the Thaksin-government, which have simply been re-termed sufficiency economy projects after the coup. Although the UNDP report of 2007 mentions TRT policies, the name of Thaksin does not appear anywhere. In a paper for the Journal of Third World Studies in fall 2007, the OTOP scheme is referred to as a sufficiency economy program (Curry/Kanchana, 2007, p. 85).

${ }^{10}$ Here, this term was chosen by the author instead of "royal development projects," as the latter expression includes all members of the royal family. Rural communities are being consulted from the beginning about any of the king's projects targeting them. This does not always seem to be the case for projects initiated by other members of the royal family. Moreover, until today the author has not noticed severe criticism about any specific project directly associated with the king, in contrast to projects started by other members of the royal family. 


\section{References}

Bank of Thailand (2007): Key Economic Indicators; http://www.bot.or.th/BOThome page/DataBank/EconData/KeyEcon/index_e.htm (last accessed on 9 November 2007)

BMJ (2004): Learning from Thailand's health reforms; http://www.bmj.com/cgi/ content/full/328/7431/103 (last accessed on 9 November 2007)

Conroy, John D. (2004): APEC and Specialized Financial Institutions: The Influence of 'Thaksinomics'; The Foundation for Development Cooperation, Brisbane, Australia

Curry, Robert L. Jr/Kanchana Sura (2007): Human Resource Development (HRD) Theory and Thailand's Sufficiency Economy Concept and Its "OTOP” Program; Journal of Third World Studies; Fall 2007; 24,2; Academic Research Library; pp. $85-94$

Earth Dialogues (2002): Globalization and Sustainable Development: Is Ethics the Missing Link?, synthesis report prepared by Green Cross International: Lyon

Evans, Peter (1996): Government Action, Social Capital and Development: Reviewing the Evidence on Synergy, World Development, Vol. 24, No. 6, pp. 1119-1132,

Kate, Daniel Ten (2007): Thaksin's score card; http://www.asiasentinel.com/index. php?option $=$ com_content\&task=view\&id $=563 \&$ Itemid $=31$ (last accessed on 9 November 2007)

Looney, Robert (2003): Thailand's Thaksinomics: a new Asian paradigm? http://www.ccc.nps.navy.mil/rsepResources/si/dec03/eastAsia.asp (last accessed on 9 November 2007)

McCargo, Duncan (2005) 'Network monarchy and legitimacy crises in Thailand', The Pacific Review, 18:4, 499 - 519

Messner, Dirk (1995): Die Netzwerkgesellschaft. Wirtschaftliche Entwicklung und internationale Wettbewerbsfähigkeit als Probleme gesellschafticher Steuerung; in Deutsches Institut für Entwicklungspolitik, DIE; Köln: Weltforum Verl.

Murphy, Colum (2006): A Tug of War for Thailand's Soul; http://www.feer.com/articles1/2006/0609/free/p023.html (last accessed on 9 November 2007)

Nelson, Michael H. (2008): Thaksin's 2005 Electoral Triumph: Looking Back From the Election in 2007; Southeast Asia Research Center, Working Paper Series, No. 98, February 2008

Pasuk Phongpaichit (2004): Financing Thaksinomics; http://pioneer.netserv.chula.ac. th/ ppasuk/financingthaksinomics.pdf (last accessed on 9 November 2007)

Pasuk Phongpaichit (2005): Developing Social Alternatives: Walking Backwards into a Khlong; in "Thailand Beyond the Crisis", pp. 161-183, ed. Peter Warr, Routledge, 2005.

Pasuk Phongpaichit (2007): Thai Politics beyond 2006 coup; "Bangkok Post", 31 July

Pasuk Phongpaichit /Baker, Chris (2002): Good Governance, Money Politics, and Honest Mistakes; Monash Asia Institute, Monash University, $2^{\text {nd }}$ May 2002

Pasuk Phongpaichit /Baker, Chris (2004): Thaksin. The Business of Politics in Thailand; Silkworm Books, Chiang Mai

Porter, Michael E. (1990): The Competitive Advantage of Nations; The Free Press, New York

Rodrik, Dani (2004): Industrial Policy for the Twenty-First Century, paper prepared for UNIDO, http://ksghome.harvard.edu/ drodrik/UNIDOSep.pdf. (last accessed on 9 November 2007)

36 | Journal of Contemporary Eastern Asia, Volume 7, No.1 
Sabel, Charles F. (2005): Bootstrapping Development: Rethinking the Role of Public Intervention in Promoting Growth, Columbia University Law School, http://siteresources.worldbank.org/KFDLP/Resources/461197-

1134496659724/bootstrapping_deve_rough_send1.pdf (last accessed on 9 November 2007)

Shuman, Michael (2005): The Common Touch; in: "Time", Vol. 165, No. 5, February $7^{\text {th }}, 2005$, pp. $16-20$

Surin Maisrikrod (2007): The Post-Coup Politics in Thailand: The Re-Emergence of Bureaucratic Governance and its Challenges; Thursday, $7^{\text {th }}$ June 2007, at the Australian National University, Canberra, Cited with the author's permission

UN-DESA (2005): World Economic and Social Survey 2006: Diverging Growth and Development, Chapter 5 - Governance, Institutions and Growth Divergence, pp. 125-146, http://www.un.org/esa/policy/wess/wess2006files/chap5.pdf. (last accessed on 9 November 2007)

UNDP (2007): Thailand Human Development Report 2007. Sufficiency Economy and Human Development; http://www.undp.or.th/NHDR2007/index.html (last accessed on 9 November 2007) 